\title{
THE MEASUREMENT OF THE CHOROIDAL THICKNESS DURING ORAL GLUCOSE TOLERANCE TESTS IN PREDIABETIC SUBJECTS: A SPECTRAL DOMAIN OPTICAL COHERENCE TOMOGRAPHY STUDY
}

\author{
PREDIYABETIK HASTALARDA YAPILAN ORAL GLIKOZ TOLERANS TESTI ESNASINDA \\ KOROID KALINLIĞININ ÖLÇÜLMESI: SPEKTRAL DOMAIN OPTIK KOHERENS \\ TOMOGRAFI ÇALIŞMASI
}

\author{
Eylem ÇAĞILTAY ${ }^{1}$ (D) Muhammed ALTINIŞIK² (D), Sjaak POUWELS ${ }^{3}$ (D) Nur DEMIR ${ }^{4}$ (D) Fahrettin AKAY ${ }^{5}$ (D) \\ University of Medical Sciences, Sultan Abdulhamid Han Training and Research Hospital, ${ }^{1}$ Department of Internal Medicine, Division \\ Endocrinology and Metabolic Diseases, ${ }^{4}$ Department of Opthalmology, Istanbul, Turkey \\ ${ }^{2}$ Celal Bayar University, Faculty of Medicine, Department of Opthalmology, Manisa, Turkey \\ ${ }^{3}$ Haaglanden Medical Center, Department of Surgery, the Hague, Netherlands \\ ${ }^{5}$ Katip Celebi University, Ataturk Training and Research Hospital, Department of Opthalmology, Izmir, Turkey
}

ORCID IDs of the authors: E.Ç. 0000-0003-3901-4015; M.A. 0000-0003-0239-0180; S.P. 0000-0002-6390-7692; N.D. 0000-0003-4764-1131; F.A. 0000-0001-9679-9379

Cite this article as: Cagiltay E, Altinisik M, Pouwels S, Demir N, Akay F. The measurement of the choroidal thickness during oral glucose tolerance tests in prediabetic subjects: a spectral domain optical coherence tomography study. J Ist Faculty Med 2020;83(3):184-92. doi: 10.26650/IUITFD.2019.0095

\section{ABSTRACT}

Objective: The aim of this study is to investigate how acute hyperglycaemic changes affect the choroid in patients with prediabetes.

Material and Method: Each subject underwent a $75 \mathrm{~g}$ oral glucose tolerance test (OGTT) after overnight fasting. The measurement of choroidal thickness (ChT) was done with new generation spectral domain optical coherence tomography (SD-OCT).

Results: Fasting Plasma Glucose (FPG) levels of the patients with only isolated Impaired Fasting Glucose (IGT) patients are higher (all $p<0.0001$ ). Mean insulin levels were also higher in patients with prediabetes than in healthy volunteers during the entire experiment (all $p<0.0001)$. Changes in ChT differed between the groups, a transient increase was observed in the mean ChT as well as subfoveal, nasal and temporal locations at the $500 \mu \mathrm{m}$ distance to fovea in prediabetes individuals. While the subfoveal ChT difference was 1.52 $\pm 4.11 \mu \mathrm{m}$ (range, $-11.00 / 24.00 \mu \mathrm{m}$ ) in prediabetes, $-0.22 \pm 1.74 \mu \mathrm{m}$ (range $-2.00 / 8.00 \mu \mathrm{m}$ ) in the control group at the first hour of the OGTT. A transient choroidal thickening occurred in the prediabetes group, while there was

\section{ÖZET}

Amaç: Akut hiperglisemik değişikliklerin prediyabetli hastalarda koroidi nasıl etkilediğini araştırmak.

Gereç ve Yöntem: Hastalara en az 8 saat kalori alınmaması sonrası $75 \mathrm{~g}$ oral glukoz tolerans testi (OGTT) uygulandı. Koroid kalınlığı (ChT), yeni nesil spektral domain optik koherens tomografi (SD-OCT) ile ölçüldü.

Bulgular: Koroid kalınlığındaki değişiklikler gruplar arasında farklılık göstermiş̧ir. Prediyabetli bireylerde, foveaya 500 um mesafedeki subfoveal, nazal ve temporal lokasyonların yanı sıra ortalama ChT'de geçici bir artış gözlenmiştir. OGTT'nin ilk saatinde; prediyabetik grupta subfoveal koroid kalınlığı farkı 1,52 $\pm 4,11$ $\mu \mathrm{m}$ (aralık, -11,00/24,00 $\mu \mathrm{m}$ ) iken, kontrol grubunda subfoveal

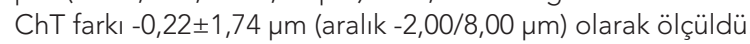

Sonuç: Akut hiperglisemik değişikliklerin anlık ölçümlerle saptanması, hastalığın oküler yapılar üzerindeki etkisini daha iyi anlamamıza yardımcı olabilir.

Anahtar Kelimeler: Koroid kalınlığı, oral glukoz tolerans testi, spektral domain optik koherens tomografi

Corresponding author/iletişim kurulacak yazar: eylem723@yahoo.com

Submitted/Başvuru: 29.11.2019 • Revision Requested/Revizyon Talebi: 20.01.2020 •

Last Revision Received/Son Revizyon: 20.01.2020 • Accepted/Kabul: 30.01.2020 • Published Online/Online Yayın: 10.03.2020

(C)Telif Hakkı $2020 \mathrm{~J}$ Ist Faculty Med - Makale metnine jmed.istanbul.edu.tr web sayfasından ulaşılabilir.

(C) Copyright 2020 by J Ist Faculty Med - Available online at jmed.istanbul.edu.tr 
no change in the healthy volunteers.

Conclusion: Detecting acute hyperglycemic changes with instant measurements may help us to better understand the effect of the disease on ocular structures.

Keywords: Choroidal thickness, oral glucose tolerance test, spectral domain optical coherence tomography

\section{INTRODUCTION}

Diabetes mellitus (DM) is characterized by chronic hyperglycaemia and fluctuations in blood glucose levels (1). The current methods to identify DM include the fasting plasma glucose (FPG) level test, the 2 hours plasma glucose value after 75-g oral glucose tolerance test (OGTT) and glycosylated hemoglobin ( $\mathrm{HbA} 1 \mathrm{c})$ level test. The previous stage of DM is prediabetes known as impaired glucose tolerance (IGT) or impaired fasting glucose (IFG), which indicate an increased risk for the future development of DM (2). IFG has identified as an FPG level of between 110 to $125 \mathrm{mg} / \mathrm{dL}$ and IGT identified as a 2 hours plasma glucose level of $140-200 \mathrm{mg} / \mathrm{dL}$ after $75 \mathrm{~g}$ oral glucose load (3).

Investigating how acute hyperglycaemic changes affect the choroid in patients with prediabetes may allow us to interpret physiological responses to metabolic changes in the eye.

Measuring choroidal thickness (ChT) in vivo has been enabled with new generation spectral domain optical coherence tomography (SD-OCT) devices. Many researchers have used the SD-OCT to investigate the pathologic and normal processes in the choroidal layer. It enables in vivo measurement of $\mathrm{ChT}$ and cross-sectional choroidal imaging. There are many studies investigating the role of the choroid in the pathogenesis of many ocular diseases such as degenerative myopia, age-related macular degeneration, central serous chorioretinopathy, diabetic retinopathy (DR), macular hole and retinitis pigmentosa (4-8).

Our hypothesis was that the response of the choroidal layer for hyperglycemia could be more dynamic and would differ between healthy individuals and prediabetic subjects. In this study, we aimed to investigate the effect of OGTT on ChT changes using OCT in prediabetics with no signs and symptoms of the ocular disease.

\section{MATERIAL AND METHOD}

This observational and prospective study was performed between April 2015 and August 2016 at the Ophthalmology Department of the Izmir Katip Celebi University Ataturk Training and Research Hospital. It was conducted according to the principles of the Declaration of Helsin$\mathrm{ki}$ and approved by the institutional ethics committee ((GATA Ethics Committee 5.5.2015/8 (218)), and informed consent was obtained from each patient. The OGTT group included 50 eyes of 50 patients with prediabetes whose FPG was 110 to $125 \mathrm{mg} / \mathrm{dL}$ and/or $2 \mathrm{~h}$ OGTT plasma glucose was 140-200 mg/dL, followed by the Endocrinology and Metabolism department. These patients underwent OGTT and were referred to the ophthalmology clinic before and during the OGTT for ophthalmological examinations. The control group included 50 eyes of 50 healthy age and sex-matched volunteers who were recruited from the healthy individuals visiting the outpatient clinic of ophthalmology. The control group received the same amount of glucose-free water. The control subjects did not have a diagnosis of any ocular or other systemic diseases. Only the right eyes of the participants were included in the study.

The inclusion criteria for both groups were: best-corrected visual acuity of at least 20/20, nonsmoking, no drug and alcohol abuse, no medication, less than 2 diopters (D) of cylindrical and/or $3 \mathrm{D}$ of spherical refractive error, and without any glaucomatous findings such as glaucomatous optic disk changes, such as excavation, notching, or focal thinning of the neuroretinal rim, peripapillary hemorrhage and glaucomatous retinal nerve fiber layer loss. Exclusion criteria included any history of retinal diseases, intraocular pressure (IOP) readings higher than $21 \mathrm{mmHg}$, any systemic abnormalities (e.g., vascular disease, hypertension, or chronic inflammatory disease), history of previous intraocular surgery or laser therapy, smoking and poor image quality because of unstable fixation or cataract.

All patients and controls underwent complete ophthalmologic examinations, including visual acuity and refraction, slit-lamp biomicroscopy, applanation tonometry, axial length (AL) by ultrasonography (OcuScan; Alcon, TX, USA) and dilated funduscopy with a 90-D lens. Systolic and diastolic blood pressures were measured using a digital automatic device (Omron Healthcare Co., Ltd. Kyoto, Japan) after participants rested for at least $10 \mathrm{~min}$. Blood pressure values of both groups were within the normal range (systolic $<120 \mathrm{~mm} \mathrm{Hg}$, diastolic $<80 \mathrm{~mm} \mathrm{Hg}$ ).

Each subject underwent an OGTT (75 g glucose) after overnight fasting. Blood glucose levels were measured with a blood glucose analyzer (HemoCue Diagnostics BV, Oisterwijk, the Netherlands). Endogenous insulin levels were measured by means of immunometric assays (Lu- 
minescence, Bayer Diagnostics, Mijdrecht, Netherlands) in the Endocrinology Laboratory at the Department of Clinical Chemistry.

Body mass index (BMI) was calculated as BMl=weight $(\mathrm{kg}) /$ height $(\mathrm{m})^{2}$.

\section{Spectral-domain optical coherence tomography scans} All participants were examined with SD-OCT (Nidek, RS3000, Gamagori, Japan) after pupillary dilation with tropicamide 1\% (Tropamid 1\%; Bilim ilaç, İstanbul, Turkey). Three images were performed for each individual and the highest signal strength (at least 7) was enrolled. Macula Line Raster scan protocol was used to assess the ChT. The ChT was measured as the perpendicular distance between the hyperreflective outer border of the retinal pigment epithelium-Bruch's membrane and choroidal-scleral interface. Two experienced physicians (F.A and M.A) who were blinded to the diagnosis of the participants who underwent the OCT scans and ChT evaluations. The ChT was measured at 7 different points: at the subfovea; at 500 $\mu \mathrm{m}, 1000 \mu \mathrm{m}$, and $1500 \mu \mathrm{m}$ temporal to the fovea; and at $500 \mu \mathrm{m}, 1000 \mu \mathrm{m}$, and $1500 \mu \mathrm{m}$ nasal to the fovea (Figure 1). The SD-OCT measurements were performed between 9:00 and 12:00 AM due to diurnal effect. The built-in follow-up feature was used to acquire scans at the same retinal position in subsequent imaging sessions.

\section{Statistical analysis}

All statistical data was analyzed using SPSS version 21.0 (SPSS Inc., Chicago, IL, USA). Values were expressed as mean \pm standard deviation. The normality of the values was analyzed by using the Shapiro-Wilk test and baseline differences between groups were analysed using unpaired t-tests or Mann-Whitney $U$ test according to distrubition pattern. Categorical data was compared using the $\chi^{2}$-test or Fisher's exact test. The results of the OGTT were analysed by repeated measures analysis of variance test (rANOVA). Bonferroni adjustment for multiple testing was applied. Differences were accepted significant at $p<0.05$. Correlations between the variables were analysed by Pearson or Spearman correlation coefficient.

\section{RESULTS}

A total of 50 prediabetic patients (31 male and 19 female) and 50 healthy subjects ( 26 male and 24 female) were enrolled in this study. The mean age of the prediabetic patients was $41.26 \pm 6.49$ years. There were no differences in sex, age, spherical equivalent (SE), IOP, BMI or AL between the two groups ( $p>0.05$ ). The mean $\mathrm{HbA} 1 \mathrm{c}$ level was higher in prediabetic group as $5.98 \pm 0.33 \%$ in the prediabetic group, $5.68 \pm 0.15 \%$ in the healthy group $(p<0.001)$. The remaining demographic, along with clinical and ophthalmologic characteristics are summarized in Table 1.
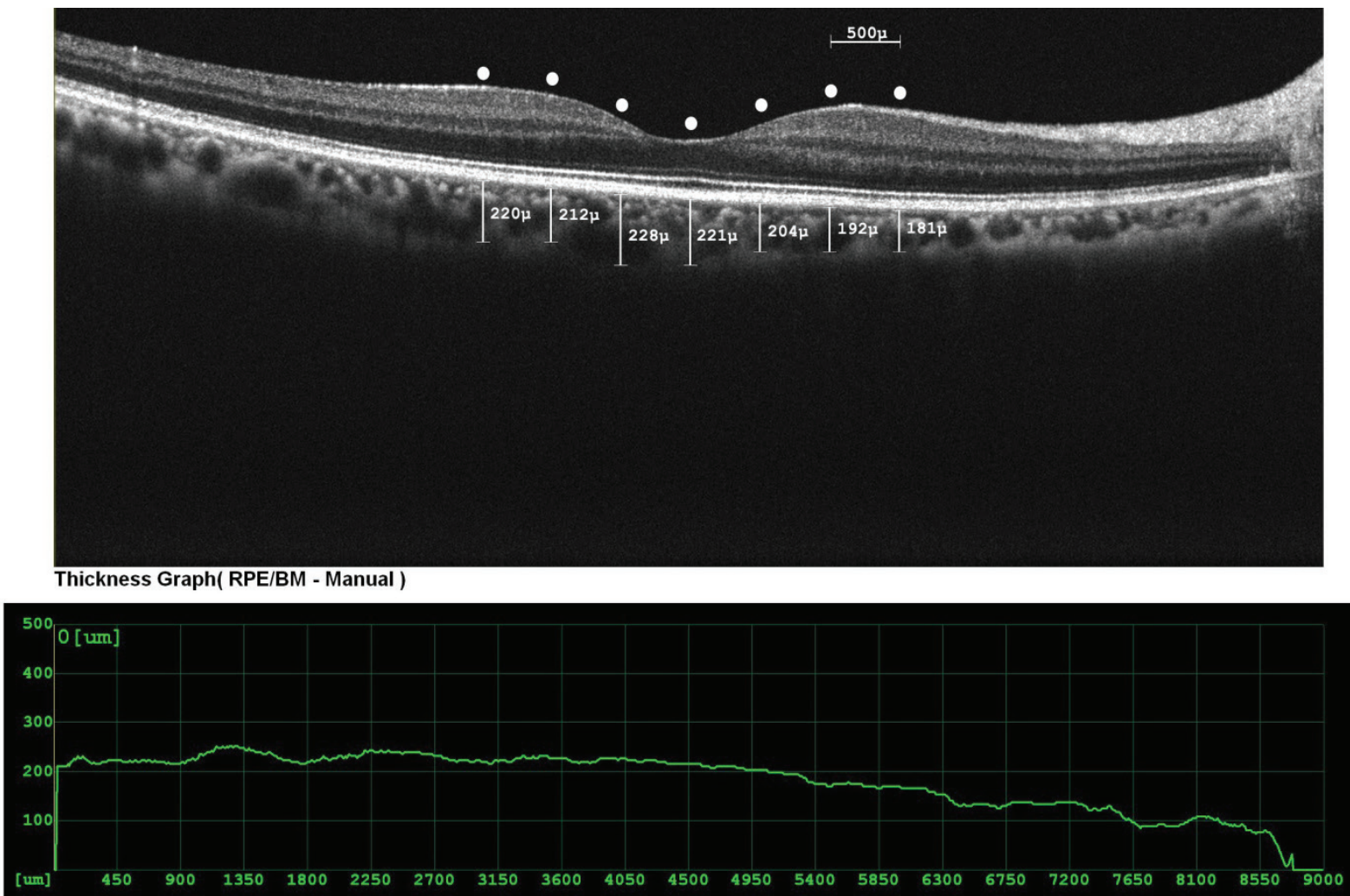

Figure 1: A sample of 7 different points measurement of ChT. 
Fasting Plasma Glucose (FPG) levels of the patients with only isolated Impaired Fasting Glucose (IGT) patients are higher than non-diabetic patients (all $p<0.0001$ ). In patients with prediabetes, mean PG increased from 114.38 \pm 5.64 $\mathrm{mg} / \mathrm{dl}$ to $187.94 \pm 33.47 \mathrm{mg} / \mathrm{dl}$ at $60 \mathrm{~min}(\mathrm{p}<0.001)$ and to the $146.6 \pm 44.53 \mathrm{mg} / \mathrm{dl}$ at $120 \mathrm{~min}$ (Table 2).

Mean insulin levels were also higher in patients with prediabetes than in healthy volunteers during the entire experiment (all $p<0.0001$, Table 3 ).

Changes in ChT differed between the groups. There was a significant difference between repeated measures in prediabetes group, whereas no changes occurred in healthy volunteers. Post hoc tests showed that this significant difference was caused in the first hour of OGTT measurement. So a transient increase was observed in the mean ChT as well as subfoveal, nasal and temporal locations at the $500 \mu \mathrm{m}$ distance to fovea in prediabetes individuals. While subfoveal ChT difference was $1.52 \pm 4.11 \mu \mathrm{m}$ (range, $-11.00 / 24.00 \mu \mathrm{m}$ ) in prediabetes, $-0.22 \pm 1.74 \mu \mathrm{m}$ (range $-2.00 / 8.00 \mu \mathrm{m}$ ) in the control group at the first hour of the OGTT.

The ChT at $1.500 \mu \mathrm{m}$ nasal distance to fovea was significantly lower in prediabetic individuals at the beginning and after 2 hours from glucose loading. Table 4 summarizes ChT measurements during OGTT.

There was no correlation between basal ChT with both $\mathrm{HbA} 1 \mathrm{c}$ and $\mathrm{BMI}$ in any groups.

Table 1: Demographic characteristics of the patients

\begin{tabular}{|c|c|c|c|}
\hline & $\begin{array}{l}\text { Prediabetic group } \\
\text { (Mean } \pm S D, \text { min-max) }\end{array}$ & $\begin{array}{c}\text { Healthy group } \\
\text { (Mean } \pm S D, \text { min-max) }\end{array}$ & $\mathrm{p}$ \\
\hline Age (years) & $41.26 \pm 6.49(30-50)$ & $41.20 \pm 6.22$ & 0.963 \\
\hline Sex (Male/female) & $31 / 19(62 \% / 38 \%)$ & $26 / 24$ (52\%/48\%) & 0.313 \\
\hline SE (D) & $-0.41 \pm 0.79(-2.00 / 1.00)$ & $-0.25 \pm 1.14(-2.50 / 2.25)$ & 0.417 \\
\hline IOP (mmHg) & $14.94 \pm 2.82(10-25)$ & $14.82 \pm 2.26(11-19)$ & 0.815 \\
\hline $\mathrm{AL}(\mathrm{mm})$ & $23.30 \pm 0.56(22.0-24.5)$ & $23.10 \pm 0.52(22.0-24.5)$ & 0.06 \\
\hline HbA1c (\%) & $5.98 \pm 0.33(5.50-6.90)$ & $5.18 \pm 0.46(4.10-5.70)$ & $<0.001$ \\
\hline BMI $\left(\mathrm{kg} / \mathrm{m}^{2}\right)$ & $26.32 \pm 1.34(23.65-29.10)$ & $25.94 \pm 1.31(23.70-29.10)$ & 0.149 \\
\hline
\end{tabular}

SE: Spherical equivalente, IOP: Intraocular pressure, AL: Axial length, BMI: Body mass index, SD: Standard deviation,

p: Statistical significance

Table 2: PG levels during OGTT

\begin{tabular}{|c|c|c|c|c|c|}
\hline PG levels & $\begin{array}{c}\text { Prediabetes } \\
(\mathrm{mg} / \mathrm{dl})\end{array}$ & $\begin{array}{c}\mathrm{p} \\
\text { (within group) }\end{array}$ & $\begin{array}{l}\text { Healthy volunteers } \\
\text { (mg/dl) }\end{array}$ & $\begin{array}{c}\mathrm{p} \\
\text { (within group) }\end{array}$ & $\begin{array}{c}\mathrm{p} \\
\text { (between groups) }\end{array}$ \\
\hline Basal & $114.38 \pm 5.64$ & & $83.98 \pm 9.65$ & & $<0.001$ \\
\hline $\begin{array}{l}1 \text { hour after } \\
\text { glucose loading }\end{array}$ & $187.94 \pm 33.47$ & $<0.001$ & $147.46 \pm 28.54$ & $<0.001$ & $<0.001$ \\
\hline $\begin{array}{l}2 \text { hour after } \\
\text { glucose loading }\end{array}$ & $146.6 \pm 44.53$ & & $96.45 \pm 23.54$ & & $<0.001$ \\
\hline
\end{tabular}

OGTT: Oral glucose tolerance test, PG: Plasma glucose

Table 3: Insulin levels during OGTT

\begin{tabular}{|c|c|c|c|c|c|}
\hline Insulin levels & $\begin{array}{c}\text { Prediabetes } \\
\text { patients }(\mu \mathrm{U} / \mathrm{mL})\end{array}$ & $\begin{array}{c}\text { P } \\
\text { (within group) }\end{array}$ & $\begin{array}{l}\text { Healthy volunteers } \\
\qquad(\mu \mathrm{U} / \mathrm{mL})\end{array}$ & $\begin{array}{c}\mathrm{p} \\
\text { (within group) }\end{array}$ & $\begin{array}{c}\mathrm{p} \\
\text { (between groups) }\end{array}$ \\
\hline Basal & $14.5 \pm 8.55$ & & $11.32 \pm 3.46$ & & $<0.001$ \\
\hline $\begin{array}{l}1 \text { hour after } \\
\text { glucose loading }\end{array}$ & $100.14 \pm 42.61$ & $<0.001$ & $73.56 \pm 26.45$ & $<0.001$ & $<0.001$ \\
\hline $\begin{array}{l}2 \text { hour after } \\
\text { glucose loading }\end{array}$ & $76 \pm 53.01$ & & $41.56 \pm 15.65$ & & $<0.001$ \\
\hline
\end{tabular}

OGTT: Oral glucose tolerance test 
Table 4: ChT measurements during OGTT

\begin{tabular}{|c|c|c|c|c|c|}
\hline ChT Measurements & $\begin{array}{l}\text { Prediabetes patients } \\
(\mu \mathrm{m})\end{array}$ & $\begin{array}{l}\mathrm{P} \text { (within } \\
\text { group) }\end{array}$ & $\begin{array}{l}\text { Healthy volunteers } \\
\qquad(\mu \mathrm{m})\end{array}$ & $\begin{array}{l}p \text { (within } \\
\text { group) }\end{array}$ & $\begin{array}{l}\mathrm{p} \text { (between } \\
\text { groups) }\end{array}$ \\
\hline Average 0 & $260.81 \pm 29.71$ & & $264.18 \pm 27.01$ & & 0.555 \\
\hline Average 1 & $262.25 \pm 29.98$ & 0.022 & $263.97 \pm 26.95$ & 0.094 & 0.764 \\
\hline Average 2 & $261.14 \pm 29.22$ & & $264.58 \pm 26.45$ & & 0.538 \\
\hline Subfoveal 0 & $267.46 \pm 29.004$ & & $271.04 \pm 27.939$ & & 0.531 \\
\hline Subfoveal 1 & $268.98 \pm 30.15$ & 0.021 & $270.82 \pm 28.31$ & 0.685 & 0.754 \\
\hline Subfoveal 2 & $267.82 \pm 28.872$ & & $270.98 \pm 27.27$ & & 0.575 \\
\hline Nazal $500 \mu \mathrm{m} 0$ & $262.04 \pm 30.15$ & & $265.96 \pm 27.7$ & & 0.5 \\
\hline Nazal $500 \mu \mathrm{m} 1$ & $264.1 \pm 30.3$ & 0.001 & $265.64 \pm 27.47$ & 0.69 & 0.791 \\
\hline Nazal $500 \mu \mathrm{m} 2$ & $263.5 \pm 29.78$ & & $266 \pm 27.3$ & & 0.663 \\
\hline Nazal 1000 um 0 & $250.8 \pm 29.73$ & & $257.7 \pm 26.63$ & & 0.225 \\
\hline Nazal 1000 um 1 & $252.66 \pm 29.24$ & 0.104 & $257.62 \pm 26.2$ & 0.527 & 0.374 \\
\hline Nazal 1000 um 2 & $251.68 \pm 28.26$ & & $258.12 \pm 26.65$ & & 0.244 \\
\hline Nazal 1500 um 0 & $235.26 \pm 33.01$ & & $247.46 \pm 26.9$ & & 0.045 \\
\hline Nazal 1500 нm 1 & $236.36 \pm 32.53$ & 0.242 & $247.38 \pm 26.87$ & 0.251 & 0.068 \\
\hline Nazal 1500 um 2 & $235.76 \pm 31.32$ & & $249.64 \pm 28.63$ & & 0.023 \\
\hline Temporal $500 \mu \mathrm{m} 0$ & $270.76 \pm 30.63$ & & $270.6 \pm 29.1$ & & 0.979 \\
\hline Temporal $500 \mu \mathrm{m} 1$ & $272.68 \pm 30.69$ & 0.018 & $270.4 \pm 29.27$ & 0.228 & 0.705 \\
\hline Temporal $500 \mu \mathrm{m} 2$ & $270.66 \pm 30.08$ & & $270.7 \pm 28.76$ & & 0.995 \\
\hline Temporal $1000 \mu \mathrm{m} 0$ & $271.24 \pm 32.24$ & & $270.54 \pm 29.32$ & & 0.91 \\
\hline Temporal $1000 \mu \mathrm{m} 1$ & $272.32 \pm 32.15$ & 0.276 & $270.34 \pm 29.27$ & 0.427 & 0.748 \\
\hline Temporal $1000 \mu \mathrm{m} 2$ & $271.34 \pm 31.64$ & & $270.6 \pm 28.83$ & & 0.903 \\
\hline Temporal $1500 \mu \mathrm{m} 0$ & $268.16 \pm 32.72$ & & $265.9 \pm 28.93$ & & 0.715 \\
\hline Temporal 1500 um 1 & $268.62 \pm 33.06$ & 0.205 & $265.64 \pm 28.77$ & 0.26 & 0.632 \\
\hline Temporal $1500 \mu \mathrm{m} 2$ & $267.16 \pm 32.19$ & & $266 \pm 28.37$ & & 0.849 \\
\hline
\end{tabular}

Results are expressed as mean \pm SD. 0: Before glucose loading 1: One hour after glucose loading 2: Two hour after glucose loading

\section{DISCUSSION}

Hyperglycemia is a condition that has various effects on the organism as well as on the eye. There have been some debates about hyperglycemia that need to be clarified. In this regard some questions such as the difference between acute or chronic effect of hyperglycemia, the levels at which begins to damage the eye, the earliest affected tissue in the eye, correlation between hyperglycemia exposure time and its effect, retinal neurodegeneration is a primary and independent change or, instead, a consequence of retinal vascular impairment, how retinal and choroidal blood flow were affected have been investigated (9).

Some models have been used to study the various forms of hyperglycemia. To evaluate the acute hyperglycemic episodes, OGTT or a glucose clamp attachment; or to in- vestigate the 3-months hyperglycemic condition, $\mathrm{HbA} 1 \mathrm{c}$ levels have been widely used (10). While it was suggested that an OGTT may provide a more similar approach to daily metabolism we used this method in this study (11).

In the present study, in the cases of healthy individuals and prediabetes, the choroidal response was evaluated in an OGTT-induced acute hyperglycemic episode. A transient choroidal thickening occurred in the prediabetes group, while there was no change in the healthy volunteers.

Changes in ChT after an acute hyperglycemic episode has only been investigated in one study to the best of our knowledge (12). Klefter et al. reported reduced ChT of healthy subjects without significant changes in DM patients contrary to our results. They claimed that this finding was probably due to a transient reduction in choroi- 
dal blood flow in healthy individuals. However, they did not analyze insulin levels and the number of the participants enrolled in the study was relatively small. In addition diabetic patients were included in that study unlike prediabetes patients in our study. In the present study we suggest that the ChT may temporarily increase in prediabetes patients unlike in healthy individuals, probably due to the fact that both insulin and glucose levels increase more than the control group. In this regard we would like to discuss the acute, subacute and chronic effect of hyperglycaemia on the choroid in this study.

DM - in addition to chronic hyperglycaemia - is a chronic disease characterized by fluctuations in glucose levels (1). For that reason, detecting acute hyperglycemic changes with instant measurements may help us to better understand the effect of the disease on ocular structures.

As a matter of fact to understand the effects of acute hyperglycaemia on the eye, systemic metabolic changes should be analyzed. There is an increase in insulin levels and glucose levels and plasma osmolality after glucose uptake via OGTT.

Two opposite hemodynamic effects of insulin have been reported: sympathetic vasoconstriction and vasodilation with direct effect via adenosine and endothelial nitric oxide $(13,14)$. In a previous study, it was shown that mild hyperinsulinemia induces an effect on pulsatile choroidal blood flow partially mediated by nitric oxide (15). Polak et al. have found increased pulsatile choroidal blood flow whereas retinal blood flow was not significantly changed (16). The different effects of insulin on the choroidal and retinal circulation attributed to the differences in sympathetic innervation in the retina and choroid that the retinal vessels do not have sympathetic innervation (17). Compatible with these findings insulin levels were higher in prediabetes patients in our study and this may contribute to the choroidal thickening.

However it was reported that glucose has potent vasodilator properties (18). Studies have not found any changes in retinal structure during acute hyperglycaemia (19, $20)$ but there is an agreement about the issue that acute hyperglycaemia increased retinal oxygen extraction (12, 21) and retinal arterial oxygen saturation (12, 22-24). Concomitantly, studies in this area have shown that hyperglycemia either increases $(25,26)$ or at least does not alter (27-29) retinal blood flow. Considering all these factors, glucose may also increase the ChT in the present study. On the other hand, whether the changes depend only on the increase in insulin levels or are caused by hyperglycemia is not clear. Hence somatostatin was given before OGTT and the insulin levels were suppressed and normoinsulinemic hyperglycemia was provided in some studies (20).
Furthermore it was suggested that serum osmolarity may be positively correlated with ChT $(30,31)$. Depending on the increase in osmolality; ocular hypotension, lens thickening, shallowing of the anterior chamber and a myopic shift in refractive index have been reported (32). There is no quantitative data associated with osmolality as a deficiency in our work, but this may be another factor that increases ChT.

Since the choroid receives $95 \%$ of all ocular blood flow and is the only blood supply of avascular fovea, choroid has been a possible target for vascular-related studies in diabetic patients and was identified an entity - diabetic choroidopathy which was associated with increased vascular tortuosity, microaneurysms, nonperfusion areas, either vascular dilations or narrowing in the choroid (3335) But the relationship between the natural course of DR and diabetic choroidopathy is still unclear. There are current studies trying to find answers to the question of if there is any predictive value in choroidal changes before developing DR.

The studies reported conflicting results. The majority of the authors reported choroidal thinning in diabetic patients without DR $(9,36-39)$. They postulated that choroidal thinning may be the earliest sign in the diabetic patients with no clinical DR and suggested that microvascular changes might occur earlier than structural changes in DM. Some OCT angiography studies supported this finding that vessel density already decreased in patients with DM before the clinical signs of DR occur $(40,41)$. Authors attributed the choroidal thinning to choriocapillaris dropout caused by hyperglycemia and hypoinsulinemia $(42,43)$. Regarding this Nagaoka et al. demonstrated decreased choroidal blood flow in diabetic patients, even before visible DR was present (8).

In contrast to these findings choroidal thickening was also reported in DM patients with no DR $(38,44)$. It was attributed to choroidal vasodilation and increase of blood flow by increased vascular endothelial growth factor (45).

The studies performed after retinopathy had developed are also controversial. In a recent study of Horváth et al. with swept source OCT, ChT was thinner in cases with more advanced DR (46). Controversially ChT increased in eyes with severe NPDR and PDR in another study (47). It has also been reported that there is no relationship between the duration of DM and ChT (48).

The possible cause of these conflicting results may be the involvement of heterogeneous and relatively small samples in the studies. A recent study provided an idea of these contradictory outcomes, Ferreira et al. reported that mean ChT increased in the first 77 months of DM, then decreased until 150 months, after which, it tended to be stabilized (38). They postulated there may be three 
phases of choroid during DM, early choroidal thickening, choroidal thinning -due to atrophy- and vascular stabilization phases where resistance and remodeling of vessels were seen.

One other reason for the conflicting results could be the number of the scoring physicians. At least two scorers must rate the results.

There was no correlation between $\mathrm{HbA} 1 \mathrm{c}$ and $\mathrm{ChT}$ in our study, in agreement with other studies (38). No change in $\mathrm{ChT}$ values with different $\mathrm{HbA} 1 \mathrm{c}$ levels may be related to an increase in resistance index in diabetic patients developed during the chronic period (49).

Our study had some limitations. ChT measurements were done manually. However, this manual technique already showed a high intraobserver and interobserver reproducibility (50). The values for intraclass correlation coefficient (ICC) between raters as well as the mean inter-observer difference should have been provided.

Also, the magnitude of the choroidal increase is relatively small. Variability in ChT measurements can arise from factors related to the observer, image quality or exact location of the measurement.

There is a much larger dispersion in the prediabetic group than in the control group as expressed by SD and min-max values. This finding could be due to clinicians diagnosing prediabetes which should be treated; emphasizing life style changes effect on the patient and the patients perception and motivation, adopting these changes which is a crutial point at the management of type two diabetes. The time between the start of the life style changes and OGTT could also be a determining factor.

This study may give an opinion that hyperglycemia and/ or hyperinsulinemia can cause different effects in the acute or chronic process in the choroid and it may have a predictive value about DR progression. Future studies were needed to clarify the exact mechanism between hyperglycemia and ocular structures as well as choroid.

Ethics Committee Approval: This study was approved by the GATA Ethics Committee (5.5.2015/8 (218)).

Informed Consent: Written consent was obtained from the participants

Peer Review: Externally peer-reviewed.

Author Contributions: Conception/Design of Study- E.C., M.A., N.D., F.A.; Data Acquisition- E.C., F.A.; Data Analysis/Interpretation- E.C., M.A., S.P., N.D., F.A.; Drafting Manuscript- E.C., M.A., S.P., N.D., F.A.; Critical Revision of Manuscript- E.C., M.A., S.P.,
N.D., F.A.; Final Approval and Accountability- E.C., M.A., S.P., N.D., F.A.; Technical or Material Support- M.A., N.D., F.A.; Supervision- E.C., M.A., S.P., F.A.

Conflict of Interest: Authors declared no conflict of interest.

Financial Disclosure: Authors declared no financial support.

Etik Komite Onayı: Bu çalışma için etik komite onayı GATA Etik Kurulu'ndan alınmıştır (5.5.2015/8 (218)).

Bilgilendirilmiş Onam: Katılımcılardan bilgilendirilmiş onam alınmıştır.

Hakem Değerlendirmesi: Dış bağımsız.

Yazar Katkıları: Çalışma Konsepti/Tasarım- E.C., M.A., N.D., F.A.; Veri Toplama- E.C., F.A.; Veri Analizi/Yorumlama- E.C., M.A., S.P., N.D., F.A.; Yazı Taslağı- E.C., M.A., S.P., N.D., F.A.; İçeriğin Eleştirel İncelemesi- E.C., M.A., S.P., N.D., F.A.; Son Onay ve Sorumluluk- E.C., M.A., S.P., N.D., F.A.; Malzeme ve Teknik DestekM.A., N.D., F.A.; Süpervizyon- E.C., M.A., S.P., F.A.

Çıkar Çatışması: Yazarlar çıkar çatışması beyan etmemişlerdir.

Finansal Destek: Yazarlar finansal destek beyan etmemişlerdir.

\section{REFERENCES}

1. Smith-Palmer J, Brandle M, Trevisan R, Orsini FM, Liabat $\mathrm{S}$, Valentine $\mathrm{W}$. Assessment of the association between glycemic variability and diabetes related complications in type 1 and type 2 diabetes. Diabetes Res Clin Pract 2014;105:27384. [CrossRef]

2. Abdul-Ghani M, Defronzo RA, Jayyousi A. Prediabetes and risk of diabetes and associated complications: Impaired fasting glucose versus impaired glucose tolerance: does it matter? Curr Opin Clin Nutr Metab Care 2016;19:394-9. [CrossRef]

3. World Health Organization. Definition and diagnosis of diabetes mellitus and intermediate hyperglycemia: report of a WHO/IDF consultation. Geneva: World Health Organization, 2006:1-50.

4. Fujiwara T, Imamura Y, Margolis R, et al. Enhanced depth imaging optical coherence tomography of the choroid in highly myopic eyes. Am J Ophthalmol 2009;148:445-50. [CrossRef]

5. Zeng J, Li J, Liu R, et al. ChT in both eyes of patients with unilateral idiopathic macular hole. Ophthalmology 2012; 119:2328-33. [CrossRef]

6. Dhoot DS, Huo S, Yuan A, et al. Evaluation of ChT in retinitis pigmentosa using enhanced depth imaging optical coherence tomography. $\mathrm{Br} J$ Ophthalmol 2013; 97:66-9. [CrossRef]

7. Kim SW, Oh J, Kwon SS, et al. Comparison of ChT among patients with healthy eyes, early age-related maculopathy, neovascular age-related macular degeneration, central serous chorioretinopathy, and polypoidal choroidal vasculopathy. Retina 2011;31:1904-11. [CrossRef]

8. Nagaoka T, Kitaya N, Sugawara R, et al. Alteration of choroidal circulation in the foveal region in patients with type 2 diabetes. Br J Ophthalmol 2004;88:1060-3. [CrossRef] 
9. Chen Q, Fan $T, W u Y$, et al. Characteristics of Retinal Structural and Microvascular Alterations in Early Type 2 Diabetic Patients. Invest Opthal Vis Sci 2018;59:2110-8. [CrossRef]

10. DeFronzo RA, Tobin JD, Andres R. Glucose clamp technique: a method for quantifying insulin secretion and resistance. Am J Physiol Metab 1979;237(3):214-23. [CrossRef]

11. Cersosimo E, Solis-Herrera C, Trautmann ME, Malloy J, Triplitt CL. Assessment of pancreatic beta-cell function: review of methods and clinical applications. Curr Diabetes Rev 2014;10:2-42. [CrossRef]

12. Klefter ON, Vilsboll T, Knop FK, et al. Retinal vascular and structural dynamics during acute hyperglycaemia. Acta Ophthalmol 2015;93:697-705. [CrossRef]

13. Anderson EA, Hoffman RP, Balon TW, Sinkey CA, Mark AL. Hyperinsulinemia produces both sympathetic neural activation and vasodilation in normal humans. J Clin Invest 1991;87:2246-52. [CrossRef]

14. Su EN, Yu DY, Alder VA, Cringle SJ, Yu PK. Direct vasodilatory effect of insulin on isolated retinal arterioles. Invest Ophthalmol Vis Sci 1996;37:2634-44.

15. Schmetterer $L$, Muller $M$, Fasching $P$, et al. Renal and ocular hemodynamic effects of insulin. Diabetes 1997;46:1868-74. [CrossRef]

16. Polak K, Dallinger S, Polska E, et al. Effects of insulin on retinal and pulsatile choroidal blood flow in humans. Arch Ophthalmol 2000;118:55-9. [CrossRef]

17. Laties AM. Central retinal artery innervation: absence of adrenergic innervation to the intraocular branches. Arch Ophthalmol 1967;77:405-409. [CrossRef]

18. Bursell SE, Clermont AC, Kinsley BT, Simonson DC, Aiello LM, Wolpert HA. Retinal blood flow changes in patients with insulin-dependent diabetes mellitus and no diabetic retinopathy. Invest Ophthalmol Vis Sci 1996;37:886-97.

19. Jeppesen P, Knudsen ST, Poulsen PL, Mogensen CE, Schmitz, Bek T. Response of retinal arteriole diameter to increased blood pressure during acute hyperglycaemia. Acta Ophthalmol Scand 2007;85:280-6. [CrossRef]

20. Wiemer NGM, Eekhoff EMW, Simsek S, et al. The effect of acute hyperglycemia on retinal thickness and ocular refraction in healthy subjects. Graefes Arch Clin Exp Ophthalmol 2008;246(5):703-8. [CrossRef]

21. Tiedeman JS, Kirk SE, Srinivas S, Beach JM. Retinal oxygen consumption during hyperglycemia in patients with diabetes without retinopathy. Ophthalmology 1998;105:3136. [CrossRef]

22. Hardarson $\mathrm{SH}$, Stefansson E. Retinal oxygen saturation is altered in diabetic retinopathy. $\mathrm{Br} \mathrm{J}$ Ophthalmol 2012;96:560-3. [CrossRef]

23. Khoobehi B, Firn K, Thompson H, Reinoso M, Beach J. Retinal arterial and venous oxygen saturation is altered in diabetic patients. Invest Ophthalmol Vis Sci 2013;54:7103-6. [CrossRef]

24. Jorgensen CM, Hardarson SH, Bek T. The oxygen saturation in retinal vessels from diabetic patients depends on the severity and type of vision-threatening retinopathy. Acta Ophthalmol 2014;92:34-9. [CrossRef]

25. Garhofer G, Kopf A, Polska E et al. Influence of exercise induced hyperlactatemia on retinal blood flow during normo- and hyperglycemia. Curr Eye Res 2004;28:351-8. [CrossRef]
26. Kida T, Harino S, Sugiyama T, Kitanishi K, Iwahashi Y, Ikeda T. Change in retinal arterial blood flow in the contralateral eye of retinal vein occlusion during glucose tolerance test. Graefe's Arch Clin Exp Ophthalmol 2002;240(5):342-7. [CrossRef]

27. Gilmore ED, Hudson C, Nrusimhadevara RK, et al. Retinal arteriolar hemodynamic response to an acute hyperglycemic provocation in early and sight-threatening diabetic retinopathy. Microvasc Res 2007;73(3):191-7. [CrossRef]

28. Fallon TJ, Maxwell DL, Kohner EM. Autoregulation of retinal blood flow in diabetic retinopathy measured by the bluelight entoptic technique. Ophthalmology 1987;94:1410-5. [CrossRef]

29. Sullivan PM, Parfitt VJ, Jagoe R, Newsom R, Kohner EM. Effect of meal on retinal blood flow in IDDM patients. Diabetes Care 1991;14:756-8. [CrossRef]

30. Elbay A, Altinisik M, Dincyildiz A, et al. Are the effects of hemodialysis on ocular parameters similar during and after a hemodialysis session? Arq Bras Oftalmol 2017;80:290-5. [CrossRef]

31. Chang IB, Lee JH, Kim JS. Changes in ChT in and Outside the Macula After Hemodialysis in Patients With End-Stage Renal Disease. Retina 2017;37:896-5. [CrossRef]

32. Furushima M, Imaizumi M, Nakatsuka K. Changes in Refraction Caused by Induction of Acute Hyperglycemia in Healthy Volunteers. Jpn J Ophthalmol 1999;43(5):398-403. [CrossRef]

33. Shiragami C, Shiraga F, Matsuo T, et al. Risk factors for diabetic choroidopathy in patients with diabetic retinopathy. Graefes Arch Clin Exp Ophthalmol 2002;240:436-42. [CrossRef]

34. Sezer T, Altinisik M, Koytak IA, Ozdemir MH. The Choroid and Optical Coherence Tomography. Turk J Ophthalmol 2016;46(1):30-7. [CrossRef]

35. Hidayat AA, Fine BS. Diabetic choroidopathy, light and electron microscopic observations of seven cases. Ophthalmology 1985;92:512-22. [CrossRef]

36. Esmaeelpour M, Považay B, Hermann B, et al. Mapping choroidal and retinal thickness variation in type 2 diabetes using three-dimensional 1060-nm optical coherence tomography. Invest Ophthalmol Vis Sci 2011;52:5311-6. [CrossRef]

37. Vujosevic S, Martini F, Cavarzeran F, et al. Macular and peripapillary ChT in diabetic patients. Retina 2012;32:178190. [CrossRef]

38. Tavares Ferreira J, Alves M, Dias-Santos A, et al. Retinal neurodegeneration in diabetic patients without diabetic retinopathy. Invest Ophthalmol Vis Sci 2016;57:6455-60. [CrossRef]

39. Pierro L, Iuliano L, Cicinelli MV, Casalino G, Bandello F. Retinal neurovascular changes appear earlier in type 2 diabetic patients. Eur J Ophthalmol 2017;27:346-51. [CrossRef]

40. Di G, Weihong Y, Xiao Z, et al. A morphological study of the foveal avascular zone in patients with diabetes mellitus using optical coherence tomography angiography. Graefes Arch Clin Exp Ophthalmol 2016;254:873-9. [CrossRef]

41. Takase N, Nozaki M, Kato A, Ozeki H, Yoshida M, Ogura Y. Enlargement of foveal avascular zone in diabetic eyes evaluated by en face optical coherence tomography angiography. Retina 2015;35:2377-83. [CrossRef] 
42. Regatieri CV, Branchini L, Carmody J, Fujimoto JG, Duker JS. ChT in patients with diabetic retinopathy analyzed by spectral-domain optical coherence tomography. Retina 2012;32:563-8. [CrossRef]

43. Querques G, Lattanzio R, Querques L, et al. Enhanced depth imaging optical coherence tomography in type 2 diabetes. Invest Ophthalmol Vis Sci 2012;53:6017-24. [CrossRef]

44. Xu J, Xu L, Du KF, et al. Subfoveal ChT in diabetes and diabetic retinopathy. Ophthalmology 2013;120:2023-8. [CrossRef]

45. Savage HI, Hendrix JW, Peterson DC, Young H, Wilkinson CP. Differences in pulsatile ocular blood flow among three classifications of diabetic retinopathy. Invest Ophthalmol Vis Sci 2004;45:4504-9. [CrossRef]

46. Horváth $H$, Kovács I, Sándor GL, Czakó C, Mallár K, Récsán $Z$, et al. Choroidal thickness changes in non-treated eyes of patients with diabetes: swept-source optical coherence tomography study. Acta Diabetologica 2018;55:927-34. [CrossRef]
47. Kim JT, Lee DH, Joe SG, Kim JG, Yoon YH. Changes in $\mathrm{ChT}$ in relation to the severity of retinopathy and macular edema in type 2 diabetic patients. Invest Ophthalmol Vis Sci 2013;54:3378-84. [CrossRef]

48. Yulek F, Ugurlu N, Onal ED, et al. Choroidal changes and duration of diabetes. Semin Ophthalmol 2014;29:80-4. [CrossRef]

49. Kawagishi $T$, Nishizawa $Y$, Emoto $M$, et al. Impaired retinal artery blood flow in IDDM patients before clinical manifestations of diabetic retinopathy. Diabetes Care 1995;18:1544-9. [CrossRef]

50. Shao L, Xu L, Chen CX, et al. Reproducibility of subfoveal ChT measurements with enhanced depth imaging by spectral-domain optical coherence tomography. Invest Ophthalmol Vis Sci 2013;54:230-3. [CrossRef] 